УДК 159.923.2:378.011.3-051

DOI https://doi.org/10.51547/ppp.dp.ua/2021.6.11

Білозерська Світлана Іванівна,

кандидат психологічних наук, доцент,

доцент кафедри психології

Дрогобицького державного педагогічного університету імені Івана Франка

ORCID ID: 0000-0001-9636-1756

\title{
ЦІННІСНІ ОРІЄНТАЦІЇ ЯК СКЛАДНИК ПРОФЕСІЙНОГО ІМІДЖУ МАЙБУТНЬОГО ПЕДАГОГА
}

\section{VALUE ORIENTATIONS AS A COMPONENT OF THE PROFESSIONAL IMAGE OF A FUTURE TEACHER}

У статті акиентовано увагу на ијіннісних орієнтаціях як основній складовій частині професійного іміджу майбутнього вчителя, адже стратегія формування професійного іміджу вчителя є нині однією з провідних у вітчизняній освіті, оскільки в його структурі, як і в структурі особистості педагога, иінності займають особливе місие. Доводиться, щзо в структурі професійного іміджу иіннісні орієнтації постають внутрішнім каркасом всієї його структури.

Розкрито сутність поняття професійний імідж, виходячи з аксіологічних позицій. Обтрунтовано важливість аксіологічного підходу у спрямованості педагогічної діяльності на формування системи гуманістичних, соиіальних, морально-духовних, професійних та особистісних цүіннісних орієнтацій особистості, без якої неможливий особистісний та професійний розвиток майбутнього педагога.

Зосереджено увагу на аксіологічних орієнтирах, які дають змогу розкривати особистісний потенціал на основі иінностей та організувати процес конструювання професійного іміджу майбутнього педагога в рамках иіннісних координат, властивих украӥнській освіті та культурі, а також акцентувати на иіннісному компоненті, щчо включає формування особистісних якостей, відповідних педагогічній діяльності.

Розглянто процес створення іміджу як складної комплексної діяльності, значна частина якої здійснюється в просторі внутрішнього світу людини. Сутність ж педагогічної діяльності полягає в тому, щз вона не може бути тільки для себе, їі сенс у переході діяльності «для себе» в діяльність для іншого, в залученні іншого до иінностей культури, у сприйнятті іншого як иінності. Природний і усталений механізм формування професійного іміджу дає змогу визначати його як спеиіально сформований образ, як результат діяльності когнітивної та афективної сфери майбутнього педагога.

Доведено, щчо імідж аксіологічно орієнтованого майбутнього педагога, його психологічні та візуальні характеристики, які виявляються в педагогічній діяльності, говорять про готовність майбутнього педагога до самоствердження, самоактуалізації, самовизначення.

Ключові слова: аксіологізація, аксіологічний підхід, педагогічна діяльність, професійний імідж, ичінності, иіннісні opiєнmauiï.

The article focuses on value orientations as a major component of the professional image of a future teacher, since the strategy of forming the professional image of a teacher is today one of the leading in the national education, because in its structure, as well as in the structure of the teacher's personality, values have a special place. It is argued that value orientations appear in the professional image as the internal framework of its entire structure.

The essence of the concept of professional image is revealed, proceeding from axiological viewpoint. It is the axiological approach that directs pedagogical activity to the formation of a system of humanistic, social, moral and spiritual, professional and personal value orientations of the individual, without which personal and professional development of the individual is impossible.

Given the need to solve psychological and pedagogical problems in the process of image formation, the axiological approach allows to reveal personal potential on the basis of values and organize the process of constructing the professional image of the future teacher within the values of Ukrainian education and culture, as well as focus on the value component which includes the formation of personal qualities related to pedagogical activities.

The process of image creation is a complex activity, a significant part of which is carried out in the sphere of the person's inner world. The essence of pedagogical activity is that it cannot be only for itself, its meaning is in the transition of activity "for oneself" into activity for another, in the involvement of that other in the values of culture, in the perception of others as a value.

The natural and established mechanism of formation of professional image allows us to define it as a specially formed image, as a result of activity of cognitive and affective sphere of the future teacher. The image of the axiologically oriented teacher, his psychological and visual characteristics, which are manifested in pedagogical activity, speak about the readiness of the teacher for self-affirmation, self-actualization, and self-determination.

Key words: axiologization, axiological approach, pedagogical activity, professional image, values, value orientations. 
Проблема цінностей неминуче виникає в ті історичні епохи, коли суспільна ідеологія терпить кризу. Саме це і спостерігається нині в сучасному українському суспільстві, де відбуваються складні і суперечливі процеси, пов'язані зі зміною їхніх сутнісних характеристик. Характерна особливість цих процесів полягає в тому, що вони пов'язані 3 ламкою світогляду, переоцінкою і переосмисленням сформованої системи поглядів і цінностей. Проте в перехідні кризові періоди розвитку виникають нові ціннісні орієнтації, нові потреби та інтереси, а на їхній основі перебудовуються і якості особистості. Орієнтирами у великому потоці зовнішньої інформації про соціальні явища суспільства виступають цінності, які визначають вибір ставлення людини до соціуму, до його професійної реалізації, характеризуючи ії життєву позицію, спрямованість прагнень, а також сумірність потреб і способів їх задоволення.

Можна стверджувати, що без ціннісного підходу не може існувати суспільство. Саме тому соціальним замовленням суспільства $€$ активна особистість, яка творчо мислить і готова до ініціативної, соціальної, освітньої та професійної діяльності. Тобто українському суспільству потрібні спеціалісти, в яких уже сформовано професійний імідж належного рівня. 3 огляду на це в теорії і практиці педагогічної освіти в центрі уваги стали питання формування професійного іміджу майбутнього вчителя, який базується на гуманістичному розвитку особистості, вихованні ії духовних цінностей.

Вибір саме аксіологічного підходу як методологічної основи формування професійного іміджу майбутніх учителів дає змогу визначити зміст цього процесу як систему цінностей, опанування яких потенційно спрямоване на реалізацію ціннісно-світоглядного складника розвитку педагогічної освіти в Україні, утвердження функціональності й універсальності гуманістичних ідей. Цей підхід проявляється в необхідності формування системи гуманістичних соціально-моральних ціннісних орієнтацій особистості, без якої неможливий розвиток суспільства, а також соціальний та професійний розвиток особистості. У випускника має скластися закінчена стійка система ціннісних орієнтацій, яка надалі іманентно визначатиме його життєвий і професійний шлях.

Водночас необхідно зауважити, що становлення особистості сучасного педагога в гармонії iз загальнолюдськими цінностями і культурою залежить від ціннісних підстав освіти. Тому нині формування професійного іміджу на основі ціннісного підходу в умовах професійного навчання $є$ досить актуальним.
Проблема функціонування ціннісної системи в освіті, аксіологічні аспекти в підготовці майбутнього вчителя, які $є$ передумовою формування професійного іміджу вивчалися такими українськими вченими, як М. Боришевський, В. Бондаренко, Т. Калюжна, I. Ткачова. На думку вчених, саме цінності додають стійкості особистості педагога, визначають моральні принципи, спрямовують інтереси і потреби, регулюють мотиваційну сферу, що є важливим у формуванні професійного іміджу $[2 ; 7 ; 13]$.

У науковій літературі значення терміна «професійний імідж» часто розкривається як уявлення про людину як про фахівця, професіонала своєї справи. Е. Бекетов вважає: «Професійний імідж це персоніфікований образ професії, тобто узагальнений, емоційно забарвлений образ типового професіонала, що має символічний характер і психологічний вплив на оточуючих» [2, с. 196]. Професійний імідж, на думку А. Калюжного, це «образ людини, який визначається професійними характеристиками, що має як позитивну, так і негативну сторони» [9, с. 14].

Як соціальний феномен, імідж майбутнього педагога розрахований на соціальні та етичні очікування, задоволення потреб суб'єктів педагогічного процесу. У соціально-педагогічній взаємодії професійний імідж забезпечує його носію оволодіння певними парадигмами-еталонами-зразками позитивного іміджу, що призводить до успіху, тоді як відсутність іміджу призводить індивіда до невдачі. Таким чином, імідж вчителя - не просто психічний образ професії, стереотип свідомості як відображення реальності, а попередньо принципово оброблена 3 метою мінімізації негативних рис та максимізації позитивних якостей майбутнього професіонала модель особистості вчителя, цілеспрямований змодельований еталон-зразок, що утворюється в певній соціокультурній ситуації.

На наш погляд, оволодіння зазначеними характеристиками та постійне їх вдосконалення дає змогу організувати процес конструювання професійного іміджу в рамках ціннісних координат.

За результатами дослідження сутності концепції цінностей I. Ткачова доходить висновку, що цінності - це сукупність реальних об'єктів (знарядь та засобів праці, споживчих товарів і т. д.) та абстрактних ідей, що мають велике значення для суспільства або особистості. Цінності виникають у практичній діяльності людей, коли вони не тільки вивчають властивості природних та соціальних явищ, але й намагаються оцінити їх із позиції встановлення їхньої користі для свого життя. Для розвитку особистості вони, з одного 
боку, є основою формування індивідуальних життєвих пріоритетів, з іншого - виконують функцію регулятора соціальної взаємодії з іншими людьми. Система індивідуальних людських цінностей $€$ результатом засвоєння нею провідних цінностей суспільства, але цей процес не може бути механічним перенесенням соціальних цінностей у людську свідомість, а є складним, багатогранним [13].

Зазначимо, що багатогранність трактування центрального для аксіології поняття «цінність» зумовлена неоднозначністю у вирішенні проблеми об'єктивного-суб'єктивного, матеріального-ідеального, індивідуального-громадського щодо характеристики ціннісної системи. В. Абушенко зазначає: «Конструктивність поняття цінність пов'язана насамперед із розробкою типологій цінностей на рівні «ідеальних типів», що забезпечує роботу зі створення емпіричних типологій. У цих випадках цінності визначаються як будь-який предмет, матеріальний або ідеальний, ідея або явище, щодо яких індивіди або групи займають позицію оцінки, приписуючи їм важливу роль у своєму житті, і прагнення до володіння якими відчувають як необхідність, або як ті, до яких прагнуть як до мети або розглядають як засіб досягнення мети, або як предмет будьякої природи, який має значимість для суб'єкта та здатність задовольняти його потреби» [1, с. 56].

В. Сластьонін та Г. Чижакова узагальнюють, що у вітчизняній філософській літературі цінність визначається як здатність речей чи ідей виступати засобом задоволення потреб окремих індивідів i соціальних груп, значення речей, ідей для життя предмета, специфічна форма виявлення відносин між суб' єктом і об'єктом із метою задоволення потреб суб'єкта, специфічні знання в структурі індивідуальної та суспільної свідомості, які є орієнтирами особистості та суспільства [11]. Нам імпонує авторське визначення цінностей як специфічних утворень у структурі індивідуальної свідомості, які $є$ ідеальними моделями та орієнтирами діяльності особистості.

Актуальність вивчення цінностей особистості в рамках професійної підготовки визначається тим фактом, що вони $є$ фундаментом ії спрямованості і світоглядної позиції в соціальному та професійному розвитку та входять у структуру професійного іміджу вчителя. Своєю чергою цінності відображають структуру, специфіку мотивів і ціннісних орієнтацій педагогічної діяльності, рівень розкриття творчого потенціалу, задоволеність повнотою реалізації професійних знань, здібностей, потреб, можливості самовираження особистості, ступінь усвідомлення власної необхідності як суб'єкта культурного розвитку, потребу в самоосвіті і саморозвитку.

Однією 3 найвідоміших наукових позицій із цього питання $є$ концепція I. Ісаєва, який виділив три ієрархічні рівні в системі педагогічних цінностей. Перший рівень - це соціально-педагогічні цінності, що поєднують ідеї, принципи, норми, правила, що регулюють освітню діяльність та спілкування. Вони сконцентровані в суспільній свідомості у формі моралі, педагогічної етики, філософії освіти та ін. Другий рівень складається 3 професійних та групових цінностей. Ця група $\epsilon$ сукупністю ідей, концепцій, норм, що регулюють професійно-педагогічну діяльність щодо самостійних професійних груп, колективів, освітніх установ різного типу. Цей набір є цілісною когнітивно-активною системою, що характеризується стабільністю і циклічністю. Третій рівень індивідуально-особистісні цінності, які є складним соціально-психологічним утворенням, що поєднує цільову і мотиваційну спрямованість орієнтацій [6]. Спираючись на думку вченого, можна говорити, що кожен майбутній педагог, асимілюючи суспільно-педагогічні та професійно-групові цінності, розбудовує власну особистісну систему цінностей.

Без звернення до цінностей, механізмів і технологій переведення суспільних цінностей в особистісні неможливе формування іміджу майбутнього фахівця. Цінності визначають змістовну основу професійної освіти, де освітній процес це передача не будь-якого, а значимого знання, що володіє певною цінністю і має бути усвідомленим і осмисленим особистістю. Університетська освіта має сприяти тому, щоб для кожного студента ці цінності відповідали змісту його життя, при цьому активуючи внутрішній аксіологічний потенціал особистості, пропонуючи йому гуманізм і творчу свободу при виборі засобів і методів самовиховання, саморозвитку та самоосвіти.

За словами Н.Ф. Голованова, «для освіти в рамках аксіологічного підходу надзвичайно важливим $\epsilon$ розуміти, що у світі цінностей сама соціокультурна реальність, життя людини та суспільства є об'єктивною. Життєві цінності стають змістом виховання; розвитку; навчання, образно кажучи, саме вони спрямовують підростаюче покоління і вирішують проблему “як жити”» [5, с. 98].

Аксіологічний підхід грунтується на процесі осмислення й оволодіння різними цінностями. Саме вони забезпечують цілісність і стійкість особистості, утворюють загальну спрямованість iï інтересів і прагнень, певну ієрархію індивідуальних переваг, формують рівень бажань особис- 
тості, тому так важливо сформувати в майбутнього педагога ціннісну систему. Однак цінності мають і особистісні прояви - ціннісні орієнтації (ставлення, переконання, інтереси, прагнення, бажання, наміри). Саме ціннісні орієнтації визначають ставлення особистості до навколишнього світу і до неї самої. Ціннісні орієнтації можна визначити як спрямованість суб'єкта на діяльність та певні цінності, які можуть формуватися в процесі цієї діяльності.

Такий підхід зумовлює процес формування професійного іміджу майбутнього вчителя як ціннісно зорієнтованої діяльності. 3 урахуванням цих положень особливого значення набуває ціннісномотиваційний компонент підготовки. Водночас формування когнітивно-процесуального компонента діяльності (знання, вміння, навички) також зумовлене ціннісними орієнтаціями особистості.

На думку В. Сластьоніна, система ціннісних орієнтацій вчителя виступає як один зі структурних утворень його професійного і особистісного розвитку. У структурі професійно педагогічної діяльності вченим охарактеризовано такі педагогічні цінності: цінності-цілі, які визначають концепцію особистості майбутнього педагога в сукупності Я-особистісного і Я-професійного; цінності-засоби як концепція педагогічного спілкування, техніки і технології, інноватики та ін.; цінності-відносини, які розкривають всю сукупність відносин педагогічного процесу і формування позиції щодо професійно-педагогічної діяльності; цінності-якості, представлені багатогранністю діяльних, поведінкових якостей особистості; цінності-знання, які визначають особистісну і професійну компетентність майбутнього педагога. Як домінуючі визначаються цінності-цілі - логічний фундамент сенсу професійної діяльності [12].

Три ієрархічні рівні в системі ціннісних орієнтацій особистості виділяє С. Бубнова. Вони відповідають трьом рівням вивчення: 1) найбільш узагальнені, абстрактні цінності: духовні, соціальні, матеріальні; 2) цінності, що закріплюються в життєдіяльності та виявляються як властивості особистості: товариськість, допитливість, активність, домінантність тощо; 3) найбільш характерні способи поведінки особистості як засобу реалізації та закріплення цінностей-властивостей [4].

Поряд із багаторівневістю, що проявляється в їхній ієрархічній будові, надзвичайно важливою властивістю системи ціннісних орієнтацій $є$ іiі багатовимірність, яка полягає в тому, що «критерій їхньої ієрархії - особистісна значимість - включає різні змістовні аспекти, зумовлені впливом різних типів та форм соціальних відносин» $[4$, с. 40$]$.
По суті, молода людина нині опиняється в точці перетину кількох ідентифікаційних полів: традиційної культури і сучасної, етнічної та полікультурної, патріархальної і феміністської, професійної та сімейно-побутової і т. д. У кожній із них відбувається «перегляд ієрархії цінностей, зумовлений опозицією аксіологічних форм свідомості і діяльності до раціоналізованих форм освоєння дійсності» [10 с. 13]. Під цими раціоналізованими формами освоєння часто розуміються вироблені століттями традиції і норми, які мають культурну зумовленість. Їх засвоєння $є$ невід'ємною частиною процесів інкультурації та соціалізації особистості. Саме професійна освіта виконує функцію вторинної соціалізації й інкультурації особистості у світі професії.

Ми схиляємося до думки науковців, згідно 3 якою цінність пронизує всі площини людської психіки - від потреб до ідеалів, містить реальний компонент поведінки. Цінності є своєрідним орієнтиром руху особистості та соціуму, сприяють їхній трансформації, визначають «майбутне обличчя» суспільства. Це пов'язано з тим, що «привласнення» особистістю цінностей соціуму сприяє формуванню системи, що самоорганізовується, породжує психічні новоутворення та спирається на них під час переходу на якісно новий суб'єктний рівень. Цінності є реальним життєвим ресурсом особистості, який формулює цілі й сенс життя, а також забезпечує реалізацію суб' єктності особистості як цілісної психологічної системи.

Повний цикл формування ціннісних орієнтацій у педагогічному вузі може містити такі етапи: уявлення студентів про цінності; усвідомлення власних ціннісних орієнтацій; прийняття ціннісної орієнтації; реалізація ціннісних орієнтацій у педагогічній діяльності та поведінці; закріплення ціннісної орієнтації в орієнтації особистості та перехід іiі у статус якості особистості, тобто у своєрідний потенційний стан; актуалізація потенційної ціннісної орієнтації, що виявляється в якостях особистості майбутнього вчителя.

Нам імпонує наукова думка Т. Калюжної про те, що процес інтерналізації ціннісних орієнтацій, здійснюваний у розвитку на основі позитивно значимих цінностей, переходить від можливості усвідомлення вербально вираженої цінності до іiі внутрішнього засвоєння 3 урахуванням позитивного емоційного сприйняття, потім до можливості ii реалізації, консолідації і навіть до здатності актуалізувати значущі для діяльності та поведінки ціннісні орієнтації [7].

Отже, ціннісні орієнтації - це порівняно стійке соціально зумовлене, вибіркове ставлення 
людини до сукупності матеріальних і духовних суспільних благ та ідеалів, що розглядаються як об'єкти, цілі чи засоби задоволення потреб життєдіяльності особистості [15]. Вони проявляються в певній спрямованості свідомості та поведінки, $€$ їхнім орієнтиром, визначаючи структуру професійного іміджу.

Розглядаючи імідж як емоційно забарвлений стереотип сприйняття образу вчителя у свідомості вихованців, колег, соціального оточення, масової свідомості, А.А. Калюжний зазначав, що в процесі його формування реальні якості тісно переплітаються 3 тими, які приписуються йому оточуючими [9].

Однак при такому підході не враховується компонент професійної освіти, який відповідає за формування особистості фахівця, що володіє впорядкованою системою ціннісних орієнтацій, що є основою для становлення професійних орієнтацій, під якими розуміються орієнтації на реалізацію професійних цілей і завдань у контексті ïx ціннісного розгляду. Це дає змогу осмислити роль цінностей як визначального початку педагогічної діяльності і об'єктивно вимагає ініціювати пошук нової ціннісної парадигми. Вона дасть змогу по-новому визначити цілі, принципи і зміст освіти майбутніх фахівців, буде перешкоджати деформації ідеї гуманізації в практиці ii реалізаціï. Орієнтація на цю тенденцію актуалізує інтеграцію ціннісних підстав традиційної та інноваційної професійної педагогічної освіти.

Теоретико-методологічний аналіз проблеми формування професійного іміджу дає змогу уявити кроки в реалізації ціннісного (аксіологічного) потенціалу в освіті студентів вузу і формування їхньої культури.

По-перше, великі можливості закладені в самому освітньо-педагогічному процесі, який розуміється як послідовний ряд порівняно самостійних і взаємопов'язаних етапів передачі і засвоєння знань і цінностей. Звісно ж, кожен окремий етап і взаємозв'язок між ними мають включати елементи вільного вибору, що поширюються і на цінності, яким віддається перевага.

По-друге, задовольнивши первинний інтерес до предмета, студент за допомогою викладача йде далі, тобто починає виявляти себе рефлексивний бік свідомості, підключається творчий і моральний потенціал.

По-третє, виявляється власне особистісний рівень відносин між студентом та викладачем, активізація і стимуляція зусиль із самоосвіти й самовиховання.

По-четверте, оскільки провідним суб'єктом аналізованого процесу виступає викладач, наяв- ність і ступінь ціннісних орієнтацій в освітньому процесі залежать від професійних і моральних якостей останнього. Викладач інтерпретує подію або явище як буття цінності.

По-п'яте, у зміст самого навчального матеріалу мають входити адекватні теоретичні уявлення (філософія, аксіологія). Ціннісний стрижень світогляду в такому разі буде досить міцним і надійним.

По-шосте, ціннісно-оцінний зв'язок виникає тоді, коли в системі «викладач-студент» студент не відволікається від своїх переживань, емоцій, а навпаки, прагне їх врахувати, спирається на особисту емоційну реакцію на те, що значиме для нього.

Таким чином, процес формування професійного іміджу необхідно розглядати з позиції його позитивного впливу на гармонізацію суб'єкт-суб'єктних відносин у системі «викладач - студент» та якісну характеристику авторитету педагога. 3 огляду на це В.Н. Черепанова визначає імідж педагога як інтегративну характеристику зовнішнього та внутрішнього змісту особистості вчителя [14].

Так, зовнішній вигляд допомагає людині звернути на себе увагу. Вчитель усім своїм зовнішнім виглядом має прихилити до себе учнів і дорослих. У манері одягатися проявляється одне з головних правил: гарно виглядати - значить виявляти повагу до оточуючих. Це означає, що вимоги до зовнішнього вигляду людини допомагають педагогові поліпшити професійний імідж.

Проте провідний складник професійного педагогічного іміджу - це внутрішня відповідність образу професії. Тут мається на увазі внутрішне ухвалення майбутнім педагогом цінностей, вироблення особистісних якостей, відповідних професії вчителя. Цьому сприятимуть адекватна самооцінка, впевненість у собі, соціальна та особиста відповідальність, бажання змінюватись і постійно самовдосконалюватися.

3 психологічного погляду інтерес становить структура іміджу, розроблена В.Н. Черепановою, яка виділяє два взаємопов'язаних складники у структурі іміджу: статичне ядро (Я-концепція, цінності, установки, знання, вміння) та більш рухливу зовнішню частину (візуальний, аудіальний, ольфакторний та кінестетичний образи). Ядро іміджу включає кілька рівнів: 1) поверхневий (містить знання про імідж, уявлення про шляхи його формування); 2) соціально фіксовані установки, що складаються на основі знань та уявлень і впливають на набір цих даних; 3) система ціннісних орієнтацій, які є основою формування іміджу; 4) глибинний (Я-концепція; цінності інтегруються в особистість, якщо не вступають у суперечність 3 Я-концепцією) [14, с. 115]. 
Внутрішня складова частина професійного іміджу - це внутрішній світ людини, уявлення про іiі духовний та інтелектуальний розвиток, інтереси, цінності, iї особистість загалом. Професійно значущими для майбутнього педагога є такі основні групи особистісних якостей:

1) якості, що дають змогу розуміти внутрішній світ учнів, співпереживати йому;

2) якості, що забезпечують володіння собою;

3) якості, що сприяють активному впливу на учня.

Теоретичний аналіз проблеми дає змогу стверджувати, що найважливішим елементом внутрішньої структури професійного іміджу є ціннісні орієнтації. Ми розглядаємо ціннісні орієнтації як складні утворення, що увібрали в себе різні рівні і форми взаємодії громадського та індивідуального в особистості, певні форми взаємодії внутрішнього і зовнішнього для особистості, специфічні форми усвідомлення особистістю навколишнього світу, свого минулого, сьогодення і майбутнього, а також суті власного Я.

Ціннісні орієнтації визначають духовний стрижень майбутнього педагога, виражають його ставлення до світу і до самого себе, впливають на спрямованість та зміст соціальної активності, наповнюють життя змістом. Вони становлять основний канал засвоєння студентами духовної культури суспільства та аксіологічних знань, $\epsilon$ системотворчим елементом світогляду.

Формування власної системи цінностей $\epsilon$ основою формування професійного іміджу майбутнього вчителя. Ця система включає цінності, пов'язані з утвердженням особистістю соціальної ролі в професійному середовищі (визнання оточенням, престиж тощо), цінності, що задовольняють потребу в педагогічному спілкуванні та розширюють його коло (спілкування 3 дітьми, колегами, батьками, обмін досвідом тощо), цінності, які спрямовані на саморозвиток творчої особистості (розвиток професійних і творчих здібностей, самовдосконалення тощо), цінності, що дають змогу самореалізуватися (втілення власних ідей тощо), і цінності, що дають змогу задовольнити прагматичні потреби (заробітна плата, відпустки, кар'єрний ріст тощо).

Отже, в основі професійного іміджу майбутнього педагога є процес оволодіння ціннісними орієнтаціями, а ідеал педагога є одним з їх проявів. Таким чином, можна стверджувати, що формування іміджу майбутнього педагога - це професійна вимога. Необхідність включення аксіологічного підходу до змісту професійної підготовки випливає як із сутності поняття «імідж педагога», так і $з$ його структури.

\section{СПИСОК ЛІТЕРАТУРИ:}

1. Абушенко В. Л. Постсоветская социология: мультипарадигмальность и «тоска» по теоретическому синтезу. Социология: теория, методы, маркетинг. 2013. № 4. С. 54-68.

2. Бекетова Е. А. К вопросу о специфике профессионального и индивидуального имиджа учителя. Имиджелогия - 2005 : феноменология, теория, практика : материалы третьего Международного симпозиума по имиджелогии / под ред. Е. А. Петровой. Москва : РИЦ АИМ, 2005. С. 192-196.

3. Боришевський М. Й. Духовні цінності в становленні особистості громадянина. Педагогіка і психологія. 1997. № 1. C. 144-150.

4. Бубнова С. С. Ценностные ориентации личности как многомерная нелинейная система. Психологически журнал. 1999. Т. 20. № 1. С. 36-44.

5. Голованова Н. Ф. Социализация и воспитание ребенка : учебное пособие для студентов высших учебных заведений. Санкт-Петербург : Речь, 2004. 272 с.

6. Исаев И. Ф. Теория и практика формирования профессиональной педагогической культуры преподавателей высшей школы. Москва : Белгород, 1993. 219 с.

7. Калюжна Т. Г. Педагогічна аксіологія в умовах модернізації професійно-педагогічної освіти : монографія. Київ : Вид-во НПУ імені М. П. Драгоманова, 2012. 128 с.

8. Калюжный А. А. Психология формирования имиджа учителя. Москва : Владос, 2004. 22 с.

9. Калюжный А. А. Технология построения имиджа учителя. Гуманитарное образование в школе : теория и практика. 2004(a). № 5. С. 13-19.

10. Леонтьев Д. А. Ценностные представления в индивидуальном и групповом сознании: виды, детерминанты и изменения во времени. Психологическое обозрение. 1998. № 1. С. 13-25.

11. Сластёнин В. А. Введение в педагогическую аксиологию : учебное пособие для студ. высш. пед. учеб. заведений. Москва : Академия, 2003. 192 с.

12. Сластенин В. А. Аксиологические основы педагогики. Москва : Школа-Пресс, 1998. 512 с.

13. Ткачова И. О. Аксіологічний підхід до організації педагогічного процесу в загальноосвітньому навчальному закладі : монографія. Луганськ : ЛНПУ ім. Тараса Шевченка; Харків : Каравела, 2006. 300 с.

14. Черепанова В. Н. Курс лекций по имиджелогии : учебное пособие. В 2 ч. Ч. 1. Тюмень : ТюмГНГУ, 2002. 186 с.

15. Шаров А. А. Исследование ценностных ориентаций. URL: http://psychology.net.ru 